\title{
Changing regional disparities in the European Union in the 2000s - convergence from different aspects
}

\author{
Mudanças nas disparidades regionais na União Européia nos anos 2000. \\ Convergências a partir de diferentes aspectos \\ L'évolution des disparités régionales dans l'Union Européenne dans les années \\ 2000. Convergences à partir des différents aspects \\ Cambios en las disparidades regionales en la Unión Europea en los años 2000. \\ Convergencias a partir de diferentes aspectos
}

\section{Máté Farkas and Pál Szabó}

\section{(2) OpenEdition}

\section{Journals}

Electronic version

URL: http://journals.openedition.org/espacoeconomia/5000

DOI: 10.4000/espacoeconomia.5000

ISSN: 2317-7837

\section{Publisher}

Núcleo de Pesquisa Espaço \& Economia

Electronic reference

Máté Farkas and Pál Szabó, « Changing regional disparities in the European Union in the 2000s convergence from different aspects », Espaço e Economia [Online], 13 | 2018, Online since 17 December 2018, connection on 22 April 2019. URL : http://journals.openedition.org/ espacoeconomia/5000; DOI : 10.4000/espacoeconomia.5000

This text was automatically generated on 22 April 2019.

(C) NUPEE 


\section{Changing regional disparities in the European Union in the 2000s - convergence from different aspects}

Mudanças nas disparidades regionais na União Européia nos anos 2000.

Convergências a partir de diferentes aspectos

L'évolution des disparités régionales dans l'Union Européenne dans les années

2000. Convergences à partir des différents aspects

Cambios en las disparidades regionales en la Unión Europea en los años 2000.

Convergencias a partir de diferentes aspectos

Máté Farkas and Pál Szabó

\section{Introduction}

"In order to promote its overall harmonious development, the Union shall develop and pursue its actions leading to the strengthening of its economic, social and territorial cohesion. In particular, the Union shall aim at reducing disparities between the levels of development of the various regions and the backwardness of the least favored regions."

(Treaty of Lisbon 2010, Article 174)

These statements above can be found in the Treaty of Lisbon, the most important international agreement and the constitutional basis of the European Union. Catching up of regions-as an important objective of the regional policy-could be intervened in different ways. If we decompose the regional policy's acknowledged development indicator (GDP per capita), it might be affected favourably either by the growth of the rate of the active population, the employment rate or the effectiveness of production. In this paper our focus is on answering mainly two questions. First, which one of the referred dimensions lies behind the weakening (?) "East-West" divide between the regions of $\mathrm{EU}$, and secondly, in this respect are the converging eastern regions similar to those in the western part of the continent? 
2 Our paper is organized as follows. The first section introduces the regional system of the $\mathrm{EU}$ and states the short history on different measurement methods of development and the EU's same practice. In the second part we amplify the relevance of decomposing the GDP per capita, than review the general characteristics of regional inequalities after the eastern enlargement (2004). In the fourth section we analyze the changing regional inequalities of the components of GDP per capita, and the changing characteristics of spatial structure. The last section concludes.

\section{System of regions and measuring development in the EU}

3 In the case of regional policy dividing a given country into regions, defining the regional development and measuring the level of development are necessary requirements, because there is need to determine the undeveloped regions as the potential beneficiaries of EU supports.

4 It's not a simple way to give a definition of the 'region', and as Bristow $(2010,5)$ argues: "[...] regional geographers have long struggled to define the boundaries of their fundamental object of study, such that what actually constitutes a region remains an object of mystery (Harrison 2006), and a vibrant source of ongoing debate". Based on different notions, ideas of the region in the discipline of geography could be grouped in different ways. According to Paasi (2002) there exists the idea of the 'pre-scientific' region, which sees the object as a practical choice, a spatial unit suiting to the purpose of collecting and representing datas with no particular conceptual role. The 'disciplinecentred' approach sees the regions as a result of research process, when they're often formal or functional classifications of empirical outcomes, and a particular geographical perspective is legitimated by them. In the notion of the 'critical' approach regions are neither neutral, nor self-evident entities, instead are fundamentally social constructions (cited in Bristow 2010).

5 Another distinct separation is what Vanhove and Klaassen (1980) suggest in their work on regional policy, namely that there exists uniform (homogenous), nodal (polarized) and planning/programming regions. This latter view is connected to the above-mentioned 'pre-scientific' notion, which is the most coherent with regional competitiveness and regional policy literature. Whilst in uniform (homogenous) regions the homogeneity (the separate spatial units can be linked together of certain common-physical, economic, social-characteristics), in polarized ones the heterogeneity (a sets of units maintaining more connections with one given pole than with any other one) constitutes the base of the region, therefore concrete factors differ from each other. Uniform and nodal regions generally evolve by different socio-economic processes, but planning regions are always created for specified objectives.

6 Within the regional policy the term 'region' is usually understood as a given scale between the nation state and local. This definition could easily be pertained to very different sub-national territories and geographical areas, such as the states of US, provinces of Canada or small-scale industrial districts as well as areas like NUTS II regions, which we're focusing on. For the regional policy there's a need for comparing the different regions with each other, and it's crucial to support the policy with defining the least developed territories. The status of different regions depends on the administrative 
status of the given country and the role of regions in the administrative and territorial system: in many countries the 'region' has administrative role, while in many other ones they have only statistical and planning function.

In the European Union the Nomenclature of Territorial Units for Statistics (NUTS) constitutes the system of regions. It was set up by Eurostat at the beginning of 1970s with the aim of providing a single uniform breakdown of territorial units for the production of regional statistics for the European Community. For practical reasons NUTS is based primarily on the institutional divisions currently being in force in the Member States ('normative criteria'): normative regions are the expression of political will; their limits are fixed according to the tasks allocated to the regional communities, to the size of population necessary to carry out these tasks efficiently and economically, and according to historical, cultural and other factors (EC 2011).

The system is a three-level hierarchical classification with much heterogeneity, because every country has sovereignty over the area of the administrative territorial system. However the NUTS regulation defines minimum and maximum population thresholds for the size of the NUTS regions (see Table).

Table 1.

Threshold values of the NUTS regions in Europe

\begin{tabular}{|l|l|l|}
\hline Level & Minimum & Maximum \\
\hline NUTS 1 & 3 million & 7 million \\
\hline NUTS 2 & 800000 & 3 million \\
\hline NUTS 3 & 150000 & 800000 \\
\hline
\end{tabular}

Source: Eurostat

9 The aim of the NUTS classification is to ensure that regions of comparable size appear at the same NUTS level, but each level still inevitably contains regions that differ greatly in terms of population, area, economic weight or administrative powers. This heterogeneity across the EU often simply reflects the situation at Member State level. Just to mention an example, at NUTS 2 level (which is the 'basic' region of the regional policy of the EU) there exist huge differences between the regions: the relative standard deviation is $83 \%$ in the case of population, and $136 \%$ in the case of area; these facts have to be considered when making regional comparisons.

10 The current NUTS nomenclature applicable from $1^{\text {st }}$ January 2012 subdivides the economic territory of the European Union into 97 regions at NUTS 1 level, 270 regions at NUTS 2 level and 1294 regions at NUTS 3 level. With the accession of Croatia in 2013 these numbers have grown to 98-272-1315 respectively. What follows is the brief introduction of the history of measuring development, later detailing to the practice of the EU.

11 In the last few years there emerged an intensive political (and academic) discourse and debate about the meaning, the sense and measuring of development, well-being and the deficiencies of the GDP based approaches. In this section with some regards of this 
discourse we look at the short history of different measuring methods, and try to reflect the actual EU's practice.

The notion of development in the scientific and philosophical discourses has a long history traced back to the era of Enlightenment (Power 2003) or in some cases earlier (Abrahamsen 2001), but it got more attention in its political context soon after the World War II. In the new geopolitical world order the USA had the leading position both in economic and in political sense as a superpower, and the confrontation between the USA and the former Soviet Union shaped the geopolitical processes of the globe.

After the war it was widely accepted, that the main object of development planning politics had to be to increase the volume of economic production (mainly via industrialization), so development had been identified with economic growth (Sachs 2000). As Offer $(2000,4)$ puts it: "[...] the output measure of GDP per head, or its annual rate of change, also became a normative benchmark for economic and even social performance, the higher the better" (our emphasis). Theories about this phenomena also predicted, that the benefits of economic growth (i.e. the increase of GDP per capita) later would spread across the whole society (it's the so called "trickle-down effect"), and inequalities between poor and rich people would reduce. Unfortunately there was evidence, that inequalities between and within countries had increased substantially (see e.g. the calculations of Maddison 2010), and the expected benefits didn't come true.

The concept of development (as economic growth) started to be contested in the 1970's, when it was redefined as something, which transcends the economic growth, and includes the requirements of redistribution, participation or human development as well. The "developmentalist" paradigm, which concentrated only to greater economic production have increasingly become unsustainable. After the "golden age", from the early 1950s to the end of 1960s attention began to shift towards the ecological, social and physical costs of affluence. The welfare value of economic growth began to be questioned by social scientists and environmentalists (see e.g. the "Social Indicator Movement" [Berger-Schmitt \& Noll 2000], or reports of the Club of Rome), and as a consequence, from the 1970s onwards new conceptualizations and indices of development have started to appear. These composite indices and alternative measures of development followed different approaches (Offer 2000). The first extended the national accounts to incorporate non-market goods and to eliminate the detrimental components (e.g. the Measure of Economic Welfare [Nordhaus \& Tobin 1972], or the Index of Sustainable Economic Welfare by Daly \& Cobb 1989). Another approach focused on social norms by means of social indicators, while the third considered the mental states as most important dimensions of human well-being by means of survey data on reported subjective feelings and experiences.

15 After some decades the number of composite indices has started to grow at first particularly in scientific analyses of some research institutes. The pioneer was the United Nations Research Institute for Social Development (UNRISD) which delivered the first multidimensional development indicators (Drewnowski \& Scott 1966; McGranahan et al. 1970). These indices included different economic and social variables which reflected to physical (nutrition, shelter, health), cultural (education, leisure, security), and higher needs (income), thereby tried to capture the meaning of well-being and development in a more complex way (Stanton 2007). Later from the early 1970s onwards other international organizations (ILO, OECD) joined into the research of composite indicators, publishing several alternative approaches for development (like the "basic needs 
approach", which was provided first by the International Labour Organization, later tested by Streeten 1981 and Stewart 1985).

The most influential, and perhaps the best known and widely accepted "alternative" development indicator is the Human Development Index, constructed by the UNDP in 1990. The theoretical background of the HDI is based on the "capabilities approach" of Nobel-prize winner Amartya Sen, who argued that the quality of life should be conceived and measured directly in terms of functionings and capabilities instead of material resources or utility. As he noted: "The central feature of well-being is the ability to achieve valuable functionings. The need for identification and valuation of the important functionings cannot be avoided by looking at something else, such as happiness, desire fulfillment, opulence or command over primary goods" (Sen 1985, 200). Published at first time, HDI were constituted by three indicators: the gross domestic product (GNP), the literacy rate among the people older than 25 years and the life expectancy at birth. These were regarded as proxy indicators of most important dimensions of human development; if these are ensured for the society, its individuals could achieve valuable life circumstances (Alkire 2005, Robeyns 2005). Although in the last two decades HDI has got into cross-fire of huge criticism, it's usually accepted as a better way to measure development than GDP does.

In the case of the EU measuring development is a crucial point for the regional policy. As we mentioned above, reducing the inequalities between countries and regions (territorial cohesion, convergence) and catching up the "backward" has been a common objective since decades. To carry out these objectives the criteria of backwardness need to be assigned which is based on the value of GDP per capita of the regions, and the GNI per capita of the countries. In the latest and recent regional policy period these were the main indicators, which the supported NUTS2 regions and countries were ascertained by. Nevertheless, measuring of a country's socio-economic performance is a recurrent problem in the EU. As many criticisms emphasize, the state of development in a certain country or region is a complex and multidimensional phenomena, which should not be restricted only to its economic factor.

In recent years there has been a shift from this narrow interpretation, which was demonstrated by a number of initiatives reflecting renewed societal and political priorities. In 2007 the European Commission (together with the European Parliament, Club of Rome, the WWF and the OECD) organized the "Beyond GDP" conference for developing indicators that complement GDP, and revealed strong support from policymakers, economic, social and environmental experts and civil society. This initiation continued in 2009 with other publications reflecting to the same problem. The Commission published a communication ("GDP and beyond - Measuring progress in a changing world") with the aim of improving, adjusting and complementing GDP with indicators that could be able to monitor social and environmental progress. The "culmination" of the mentioned events was the Stiglitz-Sen-Fitoussi report (Stiglitz et al. 2009) including recommendations on how to better measure economic performance, societal well-being and sustainability.

The report was discussed later by the European Parliament and as a consequence-and also in order to translate the recommendations of the mentioned report and the initiatives into concrete action-the European Statistical System Committee (ESSC) launched a Sponsorship Group on "Measuring Progress, Well-being and Sustainable Development". They prepared a report with about 50 concrete actions to be carried out by 2020 , predictably with forward-looking results. 
In the next section we deconstruct the EU's development indicator into three dimensions; later based on this methodology the changing regional inequalities will be analyzed.

\section{The decomposition method}

21 When one considers GDP per capita as a proxy measure for development process, it's usually forgotten, or not taken into account, that changes in the indicator could be affected by many factors. The index implicitly includes dimensions of labour productivity, the employment performance of a given area, and demographic factors; more detailed it yields information about the efficiency level of the employed resources (depending on the capital/labour ratio), the technology, public and social infrastructure, human capital, knowledge etc. (Marattin \& Salotti 2009).

Our empirical analysis is based on a model, where the representative firm use labour and capital as factor inputs. Production is given by constant returns to scale production function reads as:

$$
Y=A K^{\alpha} L^{1-\alpha}
$$

where $\mathrm{Y}$ denotes total output measured by GDP, A is total factor productivity, $\mathrm{K}$ and $\mathrm{L}$ are capital and labour, $\alpha$ and 1- $\alpha$ are output elasticities of capital and labour respectively. Dividing both sides by $\mathrm{P}$ (population) we get the following equation:

24

$$
\frac{Y}{P}=A\left(\frac{K}{L}\right)^{\alpha} \frac{L}{P}
$$

where $A\left(\frac{K}{L}\right)^{\alpha}$ reflects labour productivity, since it is equal to $\frac{Y}{L}$, which is positively related to capital intensity and total factor productivity. Moreover $\frac{L}{P}$ in (2) could be further decomposed into labour market participation (the ratio of employed persons per working age population, $\frac{L}{W A P}$ ) and into a demographic factor (the ratio of working age population per total population, $\frac{W A P}{P}$ ). Many of the respecting literature include the working hours to the labour productivity factor (see e.g. van Ark \& McGuckin 2005; Maynard 2007; Marattin \& Salotti 2009; Mourre 2009), but presumably it is strongly correlated with $\frac{Y}{L}$.

Therefore in our paper we use the following decomposition method:

$$
\frac{Y}{P}=\frac{Y}{L} * \frac{L}{W A P} * \frac{W A P}{P}
$$

with the denominations above. 
This methodology can also be found in the European Commission's Sixth Report on economic, social and territorial cohesion (EC 2014), but there exist many exemplars in the country level as well. Mezei et al. (2009) for example decomposed the indicator into a sectorial production and a sectorial employment dimension in the case of Romania, while Lengyel (2003), Nemes Nagy (2004) and Banerjee \& Jesenko (2014) used the same methodology like us, when analyzed regional economic differences in Hungary and in Slovenia. What's next in our paper is the review of the economic situation of the EU Member States' regions focusing on the changing disparities and spatial inequalities between them.

\section{Regional disparities in the European Union - a brief overview}

Over the last decades-especially after the millennium-the interest in the issue of regional disparities has been growing in the EU. After the eastern enlargement in 2004 the economic gap (expressed in GDP per capita) between the $10 \%$ of the population living in the most prosperous regions and the same percentage living in the least prosperous ones has more than doubled, comparing it to the EU15. The enlarged EU faced with great social and economic differences between the 'old' and the 'new' member states, moreover, the transition from centrally planned economies to market economies in the 1990s and the EU integration in 2004 led to a rise of regional inequalities within the Central and Eastern European countries (Lackenbauer 2004; Riedeł 2006).

Although in the mid-1990s the growth rate of the Central-European countries were higher than the EU15, the gap between these country groups remained high. Only Slovenia and Czech Republic had a GDP per head above $60 \%$ of the EU-15 average, while the others "lagged behind". In Romania and Bulgaria this value was about 26-27 percent of the EU average (EC 2004). With the accession of these countries, the population of the EU had risen almost by 80 million people, but their contribution to the gross domestic product-according to the population weight-had been scarce, and as a consequence, average GDP per capita significantly reduced.

In connection to these facts, an important aim of the EU's regional policy-since its establishment-has been to ensure territorial, social and economic cohesion between and within the member states; the reduction of regional income disparities has been a key objective. From the 1990s onwards the emergence of new growth theories, and increasing data availability have launched many empirical work on regional development in the European Union and research focusing on disparities has received considerable attention both from an academic and a policy point of view. Much of the regarding literature share the common result, that income convergence across nations was observable before the millennium, however disparities between regions within the member states appeared to persist or even to grow (cf. Puga 2001; Giannetti 2002; Terrasi 2002; EC 2003; EC 2007; Marelli \& Signorelli 2010; SmĘtkowski \& Wócjik 2012). Other widely accepted facts are, that spatial effects have an impact on the process of regional growth, i.e. neighboring regions tend to grow at similar speeds (Quah 1996; Fingleton 2003), and that the traditional core-periphery pattern of the whole European spatial structure is weakening (Szabó 2009). 
31 According to the analysis of Mourre (2009), in the end of the 2000s the main cause of low GDP per capita in the some of the EU15 countries' regions was the combination of lower hourly productivity and lower labour utilization, while in the case of EU10 this was owing to weak productivity. In this respect in the next section we focus on the period between 2005 and 2011 with the aim of analyzing the main changes of the inequalities in the mentioned factors and their spatial structure after the accession of CEE countries. For analyzing the "catching-up" of the regions, two kinds of convergence will be tested: the $\sigma$ -convergence mainly by kernel-density estimations and inequality indices, the $\beta$ convergence by regression models. Data availability determined the choice of the end of the analyzed period, thus we consider 2011 as final year. For the analysis we use the EU's database (Eurostat), namely the statistics of gross domestic product, the total and working age population and the employment datas between the abovementioned period. Our territorial frame of research consists of 272 NUTS2 units, including all regions of the 28 member states.

\section{Changing inequalities of GDP per capita after the eastern enlargement}

32 While reviewing the spatial structure of different productivity factors, some descriptive statistics also need to be mentioned. In 2005 the value of GDP per capita in the "most" developed region was 15 times higher, than in the "less" developed one, which difference decreased to 11 times in 2011. Both years the region of Inner London (UK) was the leader, and Nord-Est (RO) the lattermost, but it's worth mentioning that these values are generally higher in smaller regions which contain the capitals of a given country. The spatial structure of the total output in 2005 was rather mosaic than in 2011. In the former year the most economically developed regions (with GDP per capita over the $125 \%$ of EU average) had been found sparsely in the central zone of the continent, however in 2011-except for the mentioned capital-regions-they started to concentrate to the southern parts of Germany, and the Austro-German border side. The greatest changes compared to the EU's average gross domestic product occurred especially in some Romanian and Polish regions: e.g. Bucuresti-Ilfov had a GDP per capita value $81 \%$ of the EU average and it has reached to $122 \%$ in 2011, Mazowieckie (PL) had the same value in 2005 , and it has reached to $107 \%$.

The relative standard deviation (RSD) of the logarithm of GDP per capita shows the trend of weakening disparities across regions too, however since 2009 its value has been stagnating (see Figure 2). (The value of RSD was $4.22 \%$ in 2005, and $3.76 \%$ in 2011). However, the calculation of the relative standard deviation-while shows the fact of $\sigma$ convergence-tell us nothing about whether reduce of inequalities has been the result of catching up of poorer regions, or falling back of prosperous ones. 
Figure 1. Changing inequalities of per capita GDP (2005-2011)

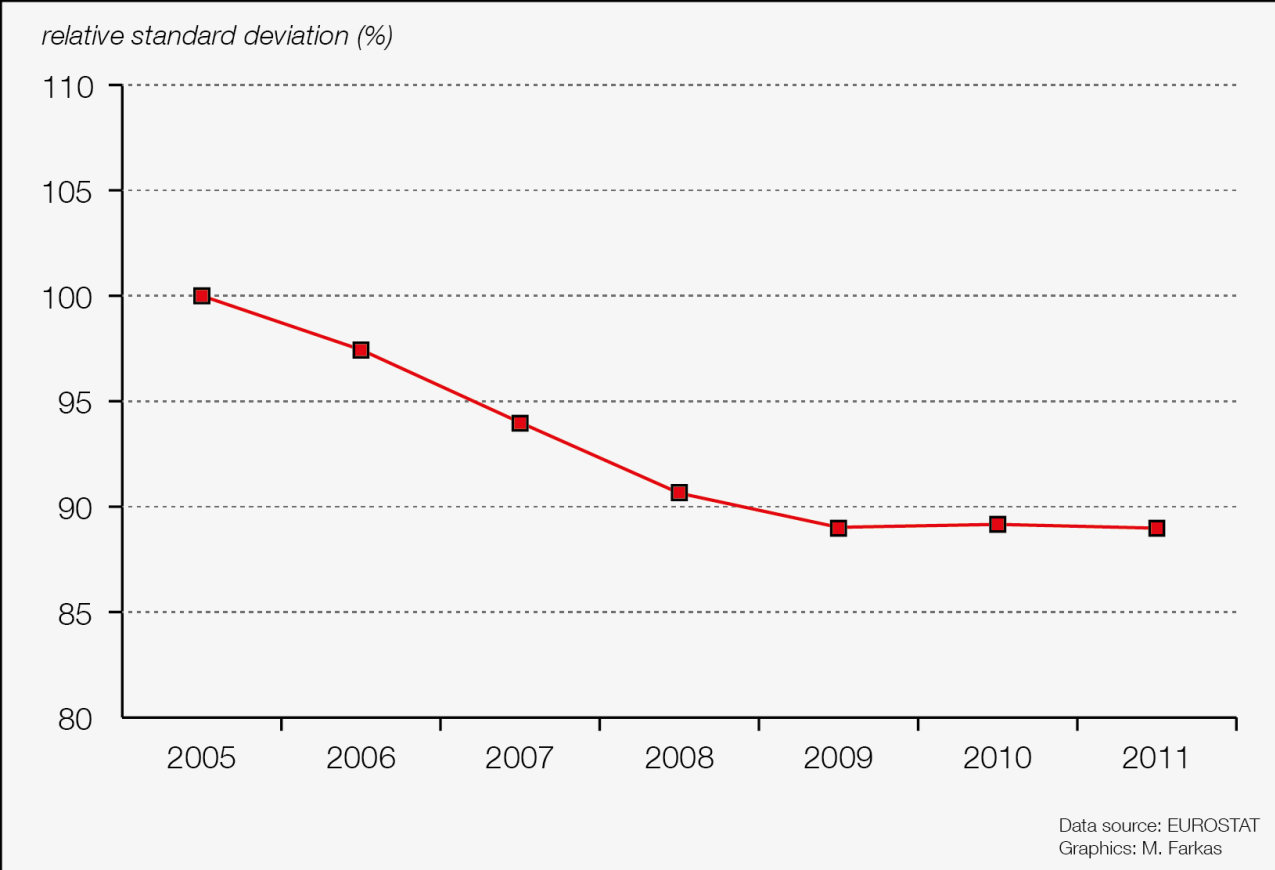

DATA SOURCE: EUROSTAT

To answer these questions we use kernel density estimates for 2005 and 2011 with optimal bandwidths proposed by Silverman (1986) supplementing it by transition matrices. The estimated density functions characterizing the distribution of GDP per capita across the regions are shown in Figure 2, which has undergone some worth mentioning changes during the analyzed period. First, it has to be noted that the formerly "poorer" regions has started to converge, the distribution has lost mess at the low end. Second, in regions near to the mode of distribution opposite processes have taken place, therefore the function has become slightly bimodal, and stretched out further in the upper part. According to our transition matrices-which show the probabilities of regions moving from a pre-defined income category in $t_{i}$ to another one in $t_{i+1}$-these results are confirmed. We made 9 categories in 2005 and 2011 with equal number of observations relative to the EU's average GDP per capita in 2005, thereby the value we've related to remained constant. The values show, that moving from the lowest category to the second, or from the second to the third has a probability of approximately $60 \%$, and it's also more probable in higher income-categories. However, the most stable categories were the highest ones: from the 27 "richest" regions 26 retained their position. The probability of mobility in the transition matrix was 73.5\% (see Major 2008 for the calculation method). 
Figure 2. Kernel-density functions of the GDP per capita dimensions

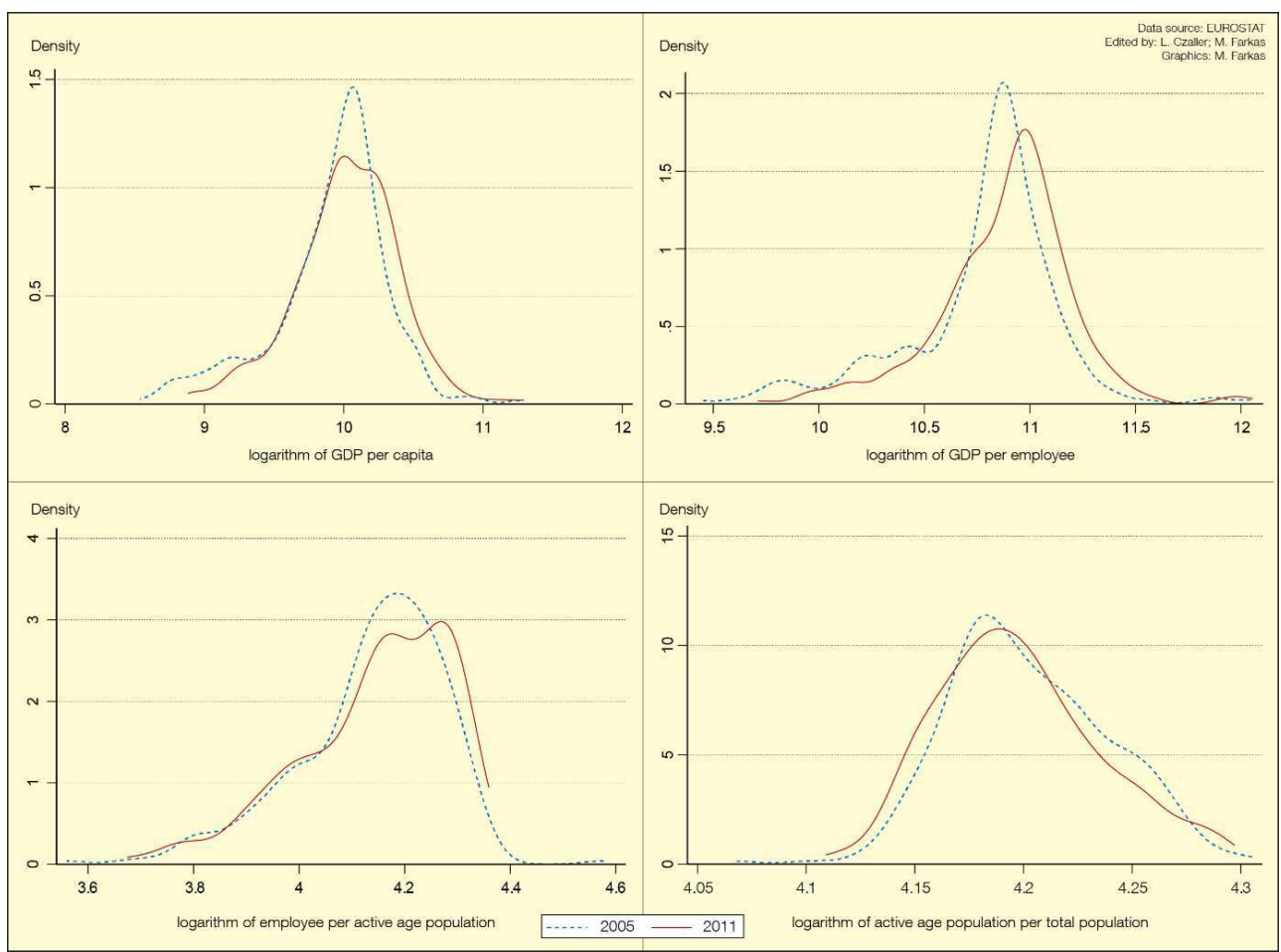

DATA SOURCE: EUROSTAT

Another approach for testing the fact of catching up is a regression estimation based on the neoclassical growth theory and the pioneer works of Baumol (1986), Barro (1991) and Barro \& Sala-i-Martin (1992), where the growth rate of different regions is explained by the initial level of GDP per capita. This method suggests that during a given period less developed regions are growing faster than more developed ones, so disparities start to reduce in the long term. Based on Sala-i-Martin (1992) we estimated the following equation:

where is the growth rate of GDP per capita between 2005 and 2011 in region $i, \alpha$ and $\beta$ are the unknown parameters, is the initial value of GDP per capita in region $i$, the $\varepsilon_{\mathrm{t}}$ is the error term. The outcomes confirm our assumptions, the $\beta$ parameter of the regression has negative sign referring to the above-mentioned phenomena with a value of -0.1396 (see Table 2). To explore the effects of the New Member States in this convergence process, we repeated the regression controlling to them with a dummy variable (NMS=1, otherwise $=0$ ).

After the inclusion of the NMS dummies, the $\beta$ parameter of the initial income level decreased, and became insignificant. Nonetheless, the control variable had a positive and highly significant parameter. So the process of convergence in a whole European level has been occurred mainly due to higher growth rates of regions in the New Member States.

Table 2: Results of the regressions among NUTS 2 regions

\begin{tabular}{|l|l|l|l|l|}
\hline $\begin{array}{l}\text { Dependent } \\
\text { variables }\end{array}$ & $\Delta$ GDP/POP & $\Delta$ GDP/EMP & $\Delta$ EMP/ACTP & $\Delta$ ACTP/POP \\
\hline
\end{tabular}




\begin{tabular}{|l|l|l|l|l|l|l|l|l|}
\hline & Model A & Model B & Model A & Model B & Model A & $\begin{array}{l}\text { Model } \\
\text { B }\end{array}$ & $\begin{array}{l}\text { Model } \\
\text { A }\end{array}$ & Model B \\
\hline $\begin{array}{l}\text { Initial } \\
\text { levels }\end{array}$ & $\begin{array}{l}0.1397^{* * *} \\
(0.0165)\end{array}$ & $\begin{array}{l}-0.0269 \\
(0.0207)\end{array}$ & $\begin{array}{l}0.1549^{* * *} \\
(0.0172)\end{array}$ & $\begin{array}{l}-0.056^{* * *} \\
(0.0213)\end{array}$ & $\begin{array}{l}0.0857^{* * *} \\
(0.0266)\end{array}$ & $\begin{array}{l}0.075^{* *} \\
(0.03)\end{array}$ & $\begin{array}{l}-0.0288 \\
(0.0265)\end{array}$ & $\begin{array}{l}0.1465^{* * *} \\
(0.0213)\end{array}$ \\
\hline $\begin{array}{l}\text { NMS } \\
\text { Dummy }\end{array}$ & $\begin{array}{l}0.1672^{* * *} \\
(0.0245)\end{array}$ & & $\begin{array}{l}0.1246^{* * *} \\
(0.0205)\end{array}$ & & 0.009 & & $0.1722^{* * *}$ \\
\hline $\mathrm{N}$ & 0.219 & 0.370 & 0.305 & 0.420 & 0.031 & 0.034 & 0.005 & 0.148 \\
\hline $\mathrm{R}^{2}$
\end{tabular}

\section{Regional inequalities of the factors of GDP per capita}

After reviewing the main processes of the GDP per capita, we try to investigate which dimension (the labour productivity, the labour market participation or the activity rate) is the most similar to it during the analyzed period, and which one has the greatest role in shaping the inequalities of total output.

In Europe the regional differences of labour productivity is very similar to that of GDP per capita, with regions having generally higher values placed in the central zone of the continent. Although, moving away from the core the spatial structure becomes mosaic in the western part, while rather homogenous in the east. This peculiarity was noticeable especially in 2005, while by 2011 some eastern regions have amended on their relative position. The fact that "capital-regions" usually have higher values is true in the case of labour productivity as well, shown by the high values of correlation coefficients between the labour productivity and total output measured by GDP per capita. Reflecting to the changes of the former indicator, 36 of 50 regions with highest growth rates are found in the New Member States-against mainly in Romania (e.g. South Muntenia, Central Region or Bucharest-Ilfov), and the Baltic States. In opposite, almost in the whole of Great Britain and in some Greek regions the level of labour productivity has decreased significantly.

If we look at the changes of regional inequalities, one can see that between 2005 and 2011 the RSD of labour productivity has followed the same path as in the case of GDP per capita until 2009, and this tendency haven't ceased from that year (Figure 3). The distribution of the indicator in question shows that the function's lower tail has shifted and slightly narrowed, while number of regions around the average has dropped effecting a faint peak beneath the average and the upper part has moved to higher values (see Figure 1). According to our regression analysis $\beta$ convergence was also observed, however the parameter's value has slightly dropped-but remained statistically significant-when controlling to the New Member States. To sum it up, in the convergence process NMS had greater role, but there were also catching up in the case of the western regions which had lowest levels of labour productivity in 2005. 
Figure 3: Inequalities of the different factors of GDP per capita (2005-2011)

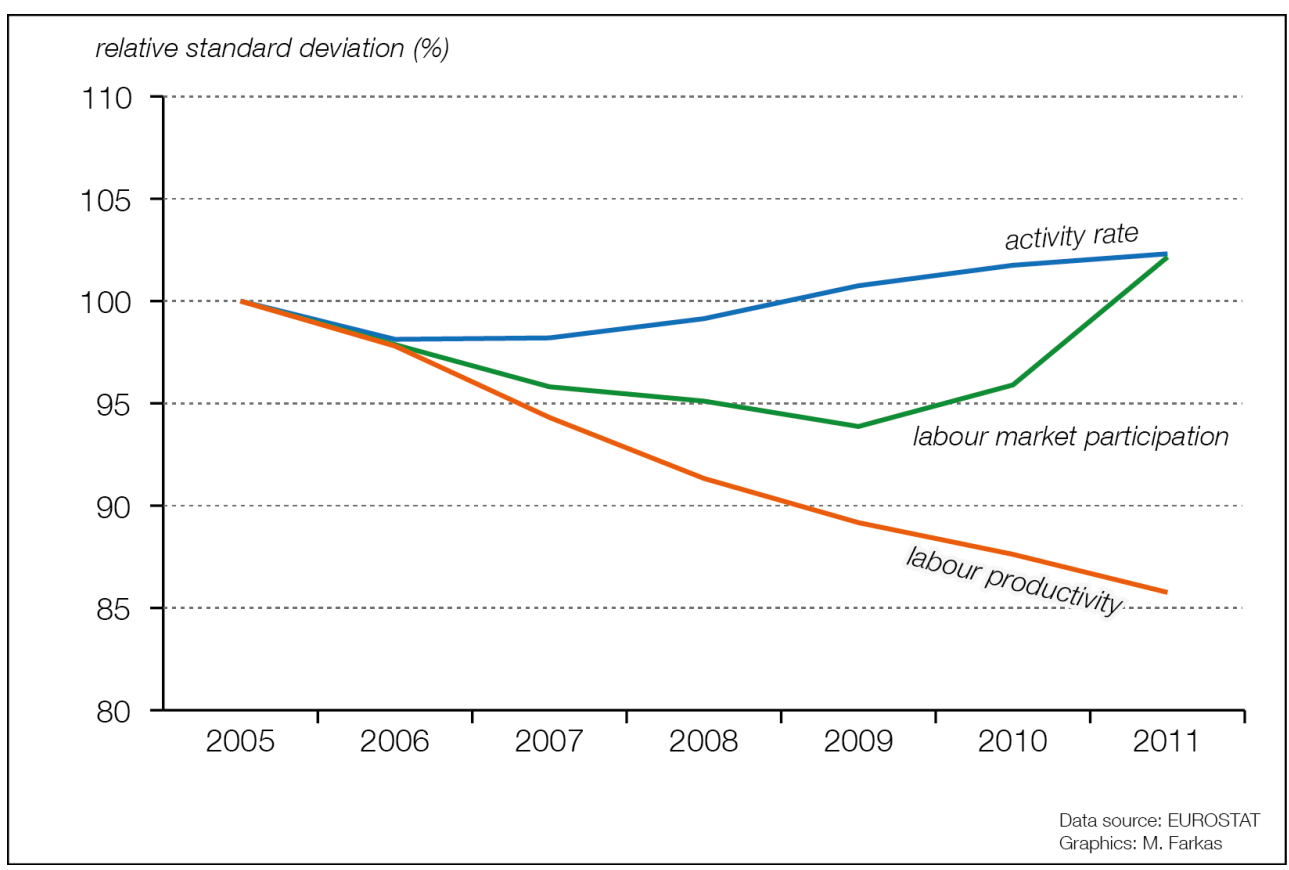

The employment rate of a given region refers to the employed persons as a percentage of the active age population (i.e. between 15-64 years). As we mentioned above, labour market participation could have an important role in shaping the economic productivity, the two indicators generally are in positive correlation (in our analysis the coefficient between them was +0.604 in 2005, and +0.608 in 2011, respectively).

Beside labour market participation, the ratio of active age population was characterized by lower inequalities (based on RSD) than GDP per capita during the five-year period. Although the trend of inequalities differs from that of productivity factors; the employment rate has followed a tendency towards equalization, but from 2009 an opposite process have been observed, while the differentiation have started in 2006 in the case of the ratio of active age population.

The spatial disparities of labour market participation were featured by a shape divide between the New Member States (+Greece) and other parts of Europe, of course one can find regions with lower level of employment in Southern Italy and in Spain as well. From the eastern side of the Union only Czech and Slovenian regions and two Baltic States (Estonia and Latvia) could reach the EU average in 2005, their number has increased with two Polish Voivodeships and a Bulgarian Planning Region. The active age population ratio on the contrary is generally higher in the Eastern part of the EU; in the 'Old' states only the capital-regions could achieve higher values than their "hinterlands". We add, that the range of the datas (related to EU average) was between cca 120 and $70 \%$ in both years, but their distribution was rather asymmetric in the case of the labour market participation. While the skewness of distribution had negative values both in 2005 and in $2011(-0.661$ and -0.585) signing that the mass of distribution was slightly concentrated over the mean, the form of function has become bimodal near to it by the end of the period. However, the distribution of the active age ratio in 2005 has been close to symmetrical with a skewness of 0.245 , and with more regions below the average. By 2011 the former value increased to 0.517 , thereby the distribution was more skewed to the right with the 
mess of regions around the $90-95 \%$ level of the EU average. As we mentioned before, in the case of this indicator there hasn't been huge differences between the regions of EU27: in 2005 the values dispersed between 110 and 86\% related to the Union's average, these extremities have been modified to 110 and $91 \%$ by 2011 , while-as we've seen in Figure 3 -the size of inequalities were $2.3 \%$ higher, than in 2005. From the 59 regions of New Member States 54 were up to the EU average in 2005 (almost half of the regions reaching this value), their number has grown to 58 by the end of the period, only Severozapaden (BG) have stayed under it. Besides the NMS regions mainly Spanish and some German units were found between the "leaders" in both years.

Returning to the changes of inequalities, the $\beta$-convergence was tested to these indicators as well, reflecting to an important rule connected to the two mentioned types of convergence hypothesis. If we look at the initial and final RSD values of employment and active age ratio, it was higher in 2011 than 2005 (which shows $\sigma$-divergence, excluding the intermediate processes). In contrary the results of linear regressions significantly show-particularly with regard to labour market participation-descending inequalities between regions. While the employment/active age population ratio indicates convergence process in a whole European level, the $\beta$ parameter in the case of active age population rate (Model A) were insignificant (but negative), in turn it has become statistically significant (as well as NMS dummy) in Model B. Therefore latter changes presumably rather occurred within the 'Old' and 'New' country groups, then in whole Europe. According to these contradictory results it could be emphasized, that $\sigma$ convergence need not accompany $\beta$-convergence: the diminishing trend of the standard deviation is not followed automatically from the significance level and the negative sign of the regression's parameter (for detailed mathematical derivation see e.g. Barro \& Salai-Martin 2004; Young et al. 2008).

By 2011, based on different socio-economic characteristics (here: economic output and its factors analyzed above) and as a consequence of diverse processes, distinct types of regions can be detached. In the southern parts of the Union (Greece, Southern Spain, Southern Italy, Croatia) and in some western regions (Nord-Pas-de-Calais, LanguedocRousillon, Ireland and some Belgian province) the levels of productivity and other dimensions are generally lower than the EU's average, thus they could be considered (only in this respect!) the least developed parts of the EU27. Another distinct zone of Europe is the countries accessed in 2004 except for their capital-regions: they can be marked by almost the same characteristics as least developed regions, but in their case the ratio of active age population is usually higher. The capital regions, the central part of Europe (concentrated in the southern parts of Germany, Western Austria and Northern Italy) completed with e.g. Cataluña, the Basque County, Belgian and Dutch units are described with higher-than-average levels in each dimension, especially in the labour market participation. There are 3 regions we consider the most developed ones: InnerLondon, Luxemburg and Brussels with the highest productivity capabilities, where the active age population rate is also reaches the EU's average, whilst labour market participation is somewhat lower than it. Other parts of Europe could be defined with ordinary productivity and labour market participation values, where the rate of active age population is the lowest in the Union. 
Figure 4: Region-types of Europe based on their productivity factors

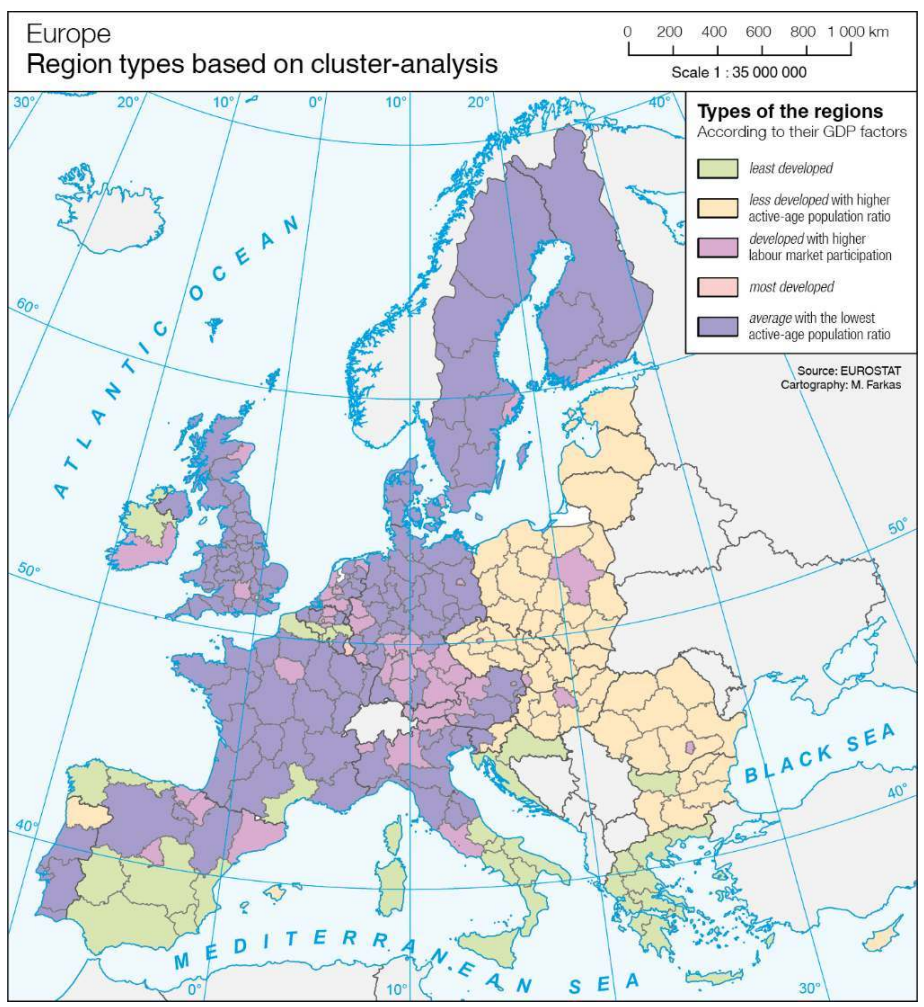

\section{Conclusions}

This paper offers a brief overview of the evolution of regional disparities within the European Union among its NUTS2 regions. Our focus is on the different factors of per capita gross domestic product, because in our suggestion - and as the datas show regions are differ from each other in their productivity factors, and in recent years these indicated clear spatial disparities with bigger coherent zones. With kernel density estimations we've shed light on changes in the distribution of the different factors, sometimes reflecting realignment within a given part of it. In almost all cases the catching-up of initially less developed regions has been noticeable, most clearly in production factors. Using socio-economic data, we show evidence of $\beta$-convergence almost in all cases, but when controlling to the New Member States, their role in shaping these processes were also often influential (e.g. in the case of per capita GDP it was undoubtedly shown). The sigma convergence on the other hand has been remarkable only when examining the total and the labour productivity, while considering the other two dimensions after some years of equalization trend the inequalities have tended to grow, and stabilized in a higher level than 2005. The paper also finds that from the New Member States in most cases only the capital regions were likely to catch up with Western ones, and have started to assimilate to them, while other parts have dropped behind. 


\section{BIBLIOGRAPHY}

Abrahamsen, Rita. 2000. Disciplining democracy: development discourse and good governance in Africa. Zed Books.

Alkire, Sabina. 2005. Why the Capability Approach?.Journal of Human Development and Capabilities 6 (1): 115-135.

Banerjee, Biswajit and Jesenko, Manca 2014. Economic Growth and Regional Disparities in Slovenia. Regional Studies.

Barro, Robert J. 1991. Economic Growth in a Cross Section of Countries. The Quarterly Journal of Economics 106 (2): 407-43.

Barro, Robert J. and Sala-i-Martin, Xavier. 1992. Convergence. Journal of Political Economy 100 (2): 223-51.

Barro, Robert J. and Sala-i-Martin, Xavier. 2004. Economic Growth, 2nd Edition, Vol. 1. The MIT Press.

Baumol, William J. 1986. Productivity Growth, Convergence, and Welfare: What the Long-run Data Show. American Economic Review 76 (5), 1072-85.

Berger-Schmitt, Regina and Noll, Heinz-Herbert 2000. Conceptual Framework and Structure of a European System of Social Indicators, EU Reporting Working Paper No. 9. Mannheim: ZUMA.

Bristow, Gillian. 2010. Critical reflections on regional competitiveness: theory, policy and practice. Routledge Studies in Human Geography. London: Routledge.

Daly, Herman and Cobb, John B. 1989. For the Common Good, Redirecting the Economy toward Community, the Environment, and a Sustainable Future. Boston: Beacon Press.

Drewnowski, Jan and Scott, Wolf. 1966. The level of living index. Geneva: United Nations Research Institute for Social Development. Report No. 4.

European Commission. 2003. Second progress report on economic and social cohesion. Brussels.

European Commission 2004. Third Report on economic and social cohesion. Luxembourg: Office for Official Publications of the European Communities.

European Commission 2007. Growing Regions, Growing Europe, Fourth Report on Economic and Social Cohesion, Office for Official Publications of the European Communities. Luxembourg: Offi ce for Official Publications of the European Communities.

European Commission 2011. Regions in the European Union. Nomenclature of territorial units for statistics. NUTS 2010/EU-27. Luxembourg: Publications Office of the European Union.

European Commission 2014. Investment for jobs and growth: Promoting development and good governance in EU regions and cities. Sixth report on economic, social and territorial cohesion. Brussels.

Fingleton, Bernard. 2003. European Regional Growth. Springer.

Giannetti, Mariassunta. 2002. The effects of integration on regional disparities: Convergence, divergence or both? European Economic Review 46 (3), 539-567. 
Harrison, John. 2006. Re-reading the new regionalism: A sympathetic critique. Space and Polity 10 (1): $21-46$

Lackenbauer, Jörg. 2004. Catching-up, Regional Disparities and EU Cohesion Policy: The Case of Hungary. Managing Global Transitions 2 (2), 123-162.

Lengyel, Imre. 2003. Verseny és területi fejlődés: térségek versenyképessége Magyarországon. [Competition and territorial development: competitiveness of regions in Hungary.] Szeged: JATEPress.

Maddison, Angus. 2010. Historical Statistics of the World Economy: 1-2008 A.D. Paris: Organization for Economic Co-operation and Development.

Marattin, Luigi and Salotti, Simone. 2009. A Note on Productivity and Per Capita GDP Growth: the Role of the Forgotten Factors (Working Papers 667). Universitá di Bologna: Dipartimento Scienze Economiche.

Marelli Enrico and Signorelli Marcello. 2010. Transition, regional features, growth and labour market dynamics. In: Caroleo F. E. \& Pastore F. (Eds.) The Labour Market Impact of the EU Enlargement, (pp. 99-147). Berlin: Springer.

Maynard, J.-P. (2007). The Comparative Level of GDP Per Capita in Canada and the United States: A Decomposition into Labour Productivity and Work Intensity Differences (The Canadian Productivity Review 2007008e). Statistics Canada, Economic Analysis.

McGranahan, D. V., Richard-Proust, C., Sovani, N. V., and Subramanian, M. 1970. Contents and measurement of socioeconomic development. New York: Praeger Publishers.

McGuckin, Robert and van Ark, Bart 2005. Productivity and participation: an international comparison (GGDC Research Memorandum 200578). Groningen Growth and Development Centre, University of Groningen.

Mezei, Elemér, Vincze, Mária, and Pakucs, Bernadett. 2009. A romániai megyék vidéki jellegének különbözősége és ennek hatása a versenyképességre. [Difference in rural characteristics of Romanian regions and its impact on competitiveness.] Területi Statisztika 12[49] (4), 441-452.

Mourre, Gilles. 2009. What explains the differences in income and labour utilisation and drives labour and economic growth in Europe? A GDP accounting perspective (European Economy Economic Papers 354). Directorate General Economic and Monetary Affairs (DG ECFIN), European Commission.

Nemes Nagy, József 2004. Új kistérségek, új városok. Új versenyzők? [New microregions, new cities. New competitors?] In Nemes Nagy, J. (ed.) Regionális tudományi tanulmányok 9. (pp. 5$42)$.

Nordhaus, William D. and Tobin, James. 1972. Is Growth Obsolete? In: Economic Research: Retrospect and Prospect Vol 5: Economic Growth (pp. 1-80). National Bureau of Economic Research, Inc.

Offer, Avner. 2000. Economic Welfare Measurements and Human Well-Being (Oxford University Economic and Social History Series 034). Economics Group, Nuffield College, University of Oxford. Paasi, Annsi. 2002. Place and Region: Regional Worlds and Words. Progress in Human Geography $26(6), 802-811$.

Power, Marcus. 2003. Rethinking Development Geographies. London, New York: Routledge:

Puga, Diego. 2001. European Regional Policies in Light of Recent Location Theories (CEPR Discussion Papers 2767). C.E.P.R. Discussion Papers. 
Quah, Danny T. 1996. Regional convergence clusters across Europe. European Economic Review 40 (3-5): 951-958.

Riedeł, Rafał. 2006. European Cohesion Facing the Problem of Growing Regional Disparities. In Tarrósy, I., \& Rosskogler, G. (Ed.), Social, economic and political cohesion in the Danube region in light of EU enlargement (pp. 48-56) Europe Centre PBC.

Robeyns, Ingrid 2005. The Capabilities Approach: A Theoretical Survey. Journal of Human Development, 6 (1), 93-114.

Sachs, Wolfgang. 2000. Development, The Rise and Decline of an Ideal. Wuppertal Papers, Nr. 108. Wuppertal Institute for Climate, Environment and Energy.

Sen, Amartya. 1985. Well-Being, Agency and Freedom: The Dewey Lectures 1984. The Journal of Philosophy 82 (4), 169-221.

SmĘtkowski, Maciej and Wójcik, Piotr. 2011. Regional Convergence in Central and Eastern European Countries: A Multidimensional Approach. European Planning Studies 20 (6), 923-939.

Stanton, Elizabeth A. 2007. The Human Development Index: A History. Amherst: University of Massachusetts, Political Economy Research Institute Working Paper 127.

Stewart, Frances. 1985. Planning to Meet Basic Needs. London: Macmillan Press.

Stiglitz, Joseph, Sen, Amartya and Fitoussi, Jean-Paul. 2009. Report by the Commission on the Measurement of Economic Performance and Social Progress.

Streeten, Paul. 1981. First Things First: Meeting Basic Human Needs in the Developing Countries. New York: Oxford University Press

Szabó, Pál 2009. Európa térszerkezete különböző szemléletek tükrében. [Spatial structure of Europe in the mirror of different hypotheses.] Földrajzi Közlemények 133 (2), 121-134.

Terrasi, Marinella. 2000. National And Spatial Factors In Eu Regional Convergence (ERSA Conference Papers). European Regional Science Association.

Vanhove, Norbert and Klaassen, Leo 1980. Regional policy: A European Approach. Rotterdam: Saxon House.

Young, Andrew T., Higgins, Matthew J. and Levy, Daniel. 2007. Sigma Convergence versus Beta Convergence: Evidence from U.S. County-Level Data (MPRA Paper 2714). University Library of Munich, Germany.

\section{ABSTRACTS}

Over the last decade the interest in researches of regional disparities in the European Union has been growing both in political and in economic cycles. After the eastern enlargement in 2004 the Union had to face with large inequalities between its regions. Several attempts were made to investigate these processes both with simple statistical, and with complex, multi-dimensional methods. In our paper we want to contribute to this discourse by reflecting the short history of measurement methods of development and later by discussing the changing inequalities between the NUTS 2 regions of Europe after 2004. We use thematic maps, inequality indices and regression models for the analysis and try to reflect the role of New Member States in shaping these processes. 
$\mathrm{Na}$ última década, o interesse ao redor de pesquisas sobre desigualdades regionais na União Européia tem aumentado tanto em termos políticos quanto econômicos. Após sua ampliação em 2004, a União Européia defrontou-se com grandes disparidades regionais. Seja com base em estatísticas simples ou métodos complexos e multi-dimensionais, várias tentativas têm ocorrido para pesquisar esses processos. No artigo em tela queremos contribuir para essa discussão recuperando um breve histórico dos métodos de mensuração do desenvolvimento para, em seguida, explorar as desigualdades mutáveis entre as regiões NUTS 2 da Europa. As análises foram feitas à luz de mapas temáticos, índices de desigualdade e modelos de regressão a fim de refletir sobre o papel dos novos estados membros na conformação daqueles processos.

Dans le dernière décennie, l'intérêt autour de recherches sur les disparités régionales dans l'Union Européenne sous le point du vue politique et économique ont augmenté. Après l'élargissement en 2004, l'UE a éprouvé des grandes disparités régionales considérables. A travers de simples statistiques ou de méthodes complexes et multidimensionelles, plusiers recherches sont en train d'évaluer ce sujet. Notre article reprend un bref historique des méthodes de mensuration du développement pour ensuite avancer vers l'évolution des inegalités entre les régions de niveau NUTS 2 de l'Europe. Les analyses ont été faites a travers des cartes thématiques, indices d'inégalités et modèles de régression à fin de reflechir sur le rôle des nouveaux États membres sur les disparités.

En la última década, el interés en torno a investigaciones sobre desigualdades regionales en la Unión Europea ha aumentado tanto en términos políticos y económicos. Tras su ampliación en 2004, la Unión Europea se enfrentó a grandes disparidades regionales. En base a estadísticas simples o métodos complejos y multi-dimensionales, se han intentado varios intentos para investigar estos procesos. En el artículo en pantalla queremos contribuir a esta discusión recuperando un breve historial de los métodos de medición del desarrollo para luego explorar las desigualdades cambiantes entre las regiones NUTS 2 de Europa. Las análisis se realizaron a la luz de mapas temáticos, índices de desigualdad y modelos de regresión para reflexionar sobre el papel de los nuevos estados miembros en la conformación de aquellos procesos.

\section{INDEX}

Keywords: regional disparities, development, European Union, convergence, economy Palavras-chave: disparidades regionais, desenvolvimento, União Européia, convergência, economia

Palabras claves: disparidades regionales, desarrollo, Unión Europea, convergencia, economía Mots-clés: disparités régionales, développement, Union Européenne, convergences, économie

\section{AUTHORS}

\section{MÁTÉ FARKAS}

Porsche Hungaria. Email: matefarkas27@gmail.com

\section{PÁL SZABÓ}

Eötvös Loránd University (ELTE), Department of Regional Science. Email: szpkact@caesar.elte.hu 